\title{
The Role of The Polish Financial SuPERVISION AUTHORITY IN THE NEW EUROPEAN ARCHITECTURE OF SUPERVISION OVER THE FINANCIAL MARKET ${ }^{1}$
}

\author{
MAGDALENA FEDOROWICZ* \\ ANNA ZALCEWICZ**
}

\section{INTRODUCTION}

Since 1 January 2008, supervision over the entire Polish financial market has been vested in the Polish Financial Supervision Authority (the Komisja Nadzoru Finansowego, KNF)2 ${ }^{2}$. However, as early as 2007, partial integration of supervision over the financial market in Poland had already taken place, although it failed to encompass the banking sector ${ }^{3}$. The Polish legislature followed the general European tendency of creating integrated supervisory systems over all sectors of national financial markets ${ }^{4}$. It should

DOI: $10.2478 /$ wrlae-2013-0011

* PhD; Institute of Law, University of Social Sciences and Humanities in Warsaw.

** PhD; Department of Public Finance Law of the European School of Law and Administration in Warsaw.

1 This paper was prepared in its original and unpublished version for a Nationwide Conference: 'The Polish Financial Supervision Authority- legal status and tasks of financial supervision in Poland' Warsaw 22 February 2010; it has been updated, however, to include the most important changes in law which have been introduced between the date it was written to the date it was to be printed (15 September 2012).

2 The Act on Financial Market Supervision of 21 July 2006 (Dz.U. (Journal of Laws) 2006, no 157, item 1119, as amended), hereinafter referred to as: The Act on Financial Market Supervision or u.n.r.f.

${ }^{3}$ It is worth mentioning that, pursuant to interim provisions, this particular situation related to the banking sector as until 1 January 2008 there was also Banking Supervisory Board (KNB). In the literature it is said that, due to legislative confunction, from 2007 to 1 January 2008 there were two supervisory authorities acting in parallel in the banking sector, KNF and KNB, Piotr Stanisławiszyn, 'Kompetencje Komisji Nadzoru Bankowego i Komisji Nadzoru Finansowego przy wykonywaniu nadzoru nad bankami w okresie przejściowym' (2007) 5 Prawo Bankowe 74ff.

${ }^{4}$ See the justification for Sejm bulletin no 654 Sejm of V tenure, dated 6.7.2006 for a draft version of an act on supervision over the financial markets, dated 21.7.2006. See also, Magdalena Fedorowicz, 'Integrierte Allfinanzaufsicht in Deutschland und Polen unter besonderer Berücksichtigung der Bankenaufsicht- eine rechtsvergleichende Analyse' (2010) 7 Opolskie Studia Administracyjno-Prawne 73-86; 'Instytucjonalna organizacja 
also be said, however, that in Poland not all the participants of the financial market were originally encompassed by integrated supervision; as was the case with cooperative savings and credit unions ${ }^{5}$ as well as entities providing payment services ${ }^{6}$.

It is worth remarking that modern changes to legal regimes governing financial markets reflect two tendencies ${ }^{7}$.

Firstly, it can be said that crises which occur on financial markets are catalysts of significant changes to national financial laws. Secondly, changes to national regulations as made prove to be insufficient and there is a need to regulate certain important issues, particularly those related to supervision over financial markets, at the international level. In the case of the former tendency, the Polish legislator decided to implement new solutions in regulations related to the functioning of the financial markets (among others, in the Act on the provision of support to financial institutions by the State Treasury ${ }^{8}$, defined by the directive on the threshold

nadzoru finansowego w krajach Unii Europejskiej’ (NBP Warsaw 2009)

$<$ http://www.nbp.pl/systemfinansowy/nadzor_finansowy_ue.pdf $>$ accessed 20 November 2012.

${ }^{5}$ Although it was suggested in the literature that cooperative savings and credit unions should be subject to the supervision of the Banking Supervisory Board (there were certain supervisory difficulties pointed out), see, among others: Anna Zalcewicz, 'Problemy prawne nadzoru Krajowej Kasy Oszczędnościowo-Kredytowej nad spółdzielczymi kasami oszczędnościowo-kredytowymi' (2004) 10 Przegląd Ustawodawstwa Gospodarczego 2531; Witold Srokosz, 'Nadzór nad spółdzielczymi kasami oszczędnościowo - kredytowymi a zintegrowany nadzór finansowy' (2007) 6 Prawo Bankowe 59ff; Witold Srokosz, 'Charakter prawny nadzoru Kasy Krajowej nad spółdzielczymi kasami oszczędnościowokredytowymi' (2007) 12 Przegląd Ustawodawstwa Gospodarczego 17ff; Marcin Olszak, 'System bankowy oraz parabankowy w Polsce' in Cezary Kosikowski and Eugeniusz Ruśkowski (eds), Finanse publiczne i prawo finansowe (3rd edn, Wolters Kluwer 2008) 222-31.

For the representatives of doctrine, the justification for introducing new supervisory solutions was the necessity of taking into account the dynamic development of cooperative savings and credit unions on the financial services market which exceeded their function and range as originally assumed by the legislator.

At present, a decision has been taken to include cooperative savings and credit unions under the supervision of the KNF, which was reflected in the passing on 5 November 2009 of an Act on Cooperative Savings and Credit Unions (Journal of Laws 2012, item 855). Its provisions in this respect are to enter into force on 27 October 2012.

${ }^{6}$ See, among others: Anna Zalcewicz, 'Nadzór Komisji Nadzoru Finansowego nad rynkiem usług płatniczych - nowe uregulowania prawne w zakresie kompetencji i zadań nadzorczych' in Eugenia Fojcik-Mastalska and Edyta Rutkowska-Tomaszewska (eds), Nadzór nad rynkiem finansowym. Aktualne tendencje i problemy dyskusyjne (2011) 1 Seria Studia Finansowoprawne 137-145.

${ }^{7}$ On the subject of evolution in banking supervision system see in particular Lesław Góral, Nadzór bankowy (Polskie Wydawnictwo Ekonomiczne 1998).

${ }^{8}$ Act of 12 February 2009 on the Provision of Financial Support by the State Treasury to Financial Institutions, Journal of Laws no 39, item 308. 
of guaranteed payments in the Act on the Bank Guarantee Fund, which is currently EUR 100000$)^{9}$. The second of the aforementioned tendencies is reflected in the actions of the European legislator. The European Commission has prepared a legislative package $^{10}$ which introduced European financial supervision from 1 January 2011, in which a special role has been given to such actors as financial market supervision authorities ${ }^{11}$ of Member States. It is also worth mentioning that financial supervision authorities of Member States, together with their national central banks, the European Central Bank and regulations on the guarantees of payments from bank guarantee funds, are elements of the safety network of the financial system, which is important from the perspective of the stability of financial markets. ${ }^{12}$ It seems that both the structure and the composition of the security system of the financial market as presented above are taking on a new form with these new elements of supervision. ${ }^{13}$ This provides a basis for considerations regarding the role and importance of the Polish Financial Supervision Authority in the European supervisory architecture.

\footnotetext{
${ }^{9}$ Act of 23 October 2008 on the Amendments to the Act on the Bank Guarantee Fund and Amendments to Other Acts, Journal of Laws no 209, item 1315.

${ }^{10}$ European Parliament and Council Regulation (EU) 1093/2010 of 24 November 2010 establishing a European Supervisory Authority (European Banking Authority), amending Decision 716/2009/EC and repealing Commission Decision 2009/78/EC [2010] OJ L331/12 (European Banking Authority Regulation); European Parliament and Council Regulation (EU) 1094/2010 of 24 November 2010 establishing a European Supervisory Authority (European Insurance and Occupational Pensions Authority), amending Decision 716/2009/EC and repealing Commission Decision 2009/79/EC [2010] OJ L331/48 (European Insurance and Occupational Pensions Authority Regulation); European Parliament and Council Regulation (EU) 1095/2010 of 24 November 2010 establishing a European Supervisory Authority (European Securities and Markets Authority), amending Decision 716/2009/EC and repealing Commission Decision 2009/77/EC [2010] OJ L331/84 (European Securities and Markets Authority Regulation); European Parliament and Council Directive 2010/78/EU of 24 November 2010 amending Directives 98/26/EC, 2002/87/EC, 2003/6/EC, 2003/41/EC, 2003/71/EC, 2004/39/EC, 2004/109/EC, 2005/60/EC, 2006/48/EC, 2006/49/EC and 2009/65/EC in respect of the powers of the European Supervisory Authority (European Banking Authority), the European Supervisory Authority (European Insurance and Occupational Pensions Authority) and the European Supervisory Authority (European Securities and Markets Authority) [2010] OJ L331/120.

${ }^{11}$ Magdalena Fedorowicz, 'Normatywne aspekty regulacji europejskiego nadzoru finansowego ze szczególnym uwzględnieniem europejskiego nadzoru w prawie bankowym' in Anna Dobaczewska, Edward Juchniewicz, Tomasz Sowiński (eds), System finansów publicznych. Prawo finansowe wobec wyzwań XXI wieku (CeDeWu 2010) 299-307; Anna JurkowskaZeidler, 'Nowe europejskie ramy ochrony stabilności wewnętrznego rynku finansowego bankowym' in Anna Dobaczewska, Edward Juchniewicz, Tomasz Sowiński (eds), System finansów publicznych. Prawo finansowe wobec wyzwań XXI wieku (CeDeWu 2010) 195-204; Anna Zalcewicz, 'Zmiany struktury instytucjonalnej i koncepcji nadzoru nad jednolitym rynkiem finansowym UE' bankowym' in Anna Dobaczewska, Edward Juchniewicz, Tomasz Sowiński (eds) (n 11) 231-40; Piotr Stanisławiszyn, 'Perspektywy zmian europejskich regulacji w zakresie nadzoru finansowego w 2011 r.' in Jan Szambelańczyk (ed), Wyzwania regulacyjne wobec doświadczeń globalnego kryzysu finansowego (SGH 2011) 131.

${ }^{12}$ This issue is described widely in Polish literature on the subject by Anna JurkowskaZeidler, Bezpieczeństwo rynku finansowego $w$ świetle prawa Unii Europejskiej (Wolters Kluwer 2008).

13 See the position of KNF, dated 14 October 2009 on the 'Reform of the European supervisory architecture'.
} 
The purpose of this paper is to analyse the main provisions of the regulation of European financial supervision from the perspective of the competencies and functions of the Polish Financial Supervision Authority (KNF). It was also considered necessary by the authors to present the current tasks, aims and competencies of the KNF. The answer to questions about the spheres of the European supervisory structure in which the activities of the Polish Financial Supervision Authority may prove to be of particular significance seems very important and interesting ${ }^{14}$. Undoubtedly, the European legislator has put before all the domestic supervisory authorities of the Member States, and thereby before the KNF, new, additional tasks whose reliable and scrupulous performance is supposed to add to the stability and greater transparency of the EU financial markets. Analysis of the packet of European financial supervision regulations as introduced in the EU leads to the conclusion that there are several current and future potential areas of activity for the KNF.

\section{COMPETENCIES AND TASKS OF THE KNF AS A SUPERVISORY AUTHORITY OF THE FINANCIAL MARKETS IN POLAND}

Pursuant to the Act on Financial Market Supervision, the KNF provides supervision over the financial markets, which includes: supervision over banks, the pension system, the insurance system, capital market, electronic money institutions, payment institutions and payment services bureaus, cooperative savings and credit unions (SKOK) and the National Cooperative Savings and Credit Union $(\mathrm{KSKOK})^{15}$. It also provides supplementary supervision. The aforementioned allows for the conclusion that the Polish legislator has applied the concept of integrated supervision over the entirety of the financial markets.

The legal structure of the regulation, which defines the scope of the activities of the KNF, was based on the concept of providing aims and resultant tasks for the entirety of the financial markets. Certain competencies have also been assigned in particular areas of supervision ${ }^{16}$ to which the theory of law prescribes tasks.

\footnotetext{
14 On the subject of the essence of European financial supervision see Magdalena Fedorowicz, 'Nowy europejski nadzór finansowy ze szczególnym uwzględnieniem nadzoru bankowego - pojęcie, istota prawna i funkcje' (2010) 630 Zeszyty Naukowe Uniwersytetu Szczecińskiego, 22 Roczniki Prawnicze 59-75.

15 Supervision over cooperative savings and credit unions and the National Cooperative Savings and Credit Union will be taken by KNF on 27 October 2012 (n 5).

${ }^{16}$ However, in some segments of the market the legislator decided not to define supervisory tasks (e.g. regulation of banking supervision, regulation of supervision over payment institutions and payment services bureaus), indicating only its aims.
} 
The general purposes of supervision are stated in the Act on Financial Market Supervision, which is to ensure the proper functioning of the financial markets; their stability, security and transparency; trust in them; and the protection of participants. Following these, those purposes are modified and made more precise for particular segments of the markets in separate legal acts.

In the capital markets, the purpose of supervision is to ensure their proper functioning, in particular the security of turnover and the protection of investors and other participants, and also obedience to the rules of fair turnover. In respect of the banking market, the purpose of supervision is firstly to guarantee the safety of capital as accumulated in the form of all manner of bank deposits, and secondly to ensure the congruence of a bank's activities with the law. However, the supervisory authority appraises this congruence in the sphere of banking activities ${ }^{17}$. Regarding the insurance market, the aim of supervision is the protection of the interests of the insurers, insured persons, and beneficiaries of insurance policies, members of pension funds, participants in pension schemes, and persons entitled to capital-based pensions or their beneficiaries ${ }^{18}$. The purpose of supervision over electronic money institutions is to ensure that institutions dealing with electronic money fulfil their obligations upon issuing it, and congruence of the actions of electronic money institutions with the law (the Act on electronic money institutions, statutes, decisions granting permission for initiating and conducting activity, and other decisions and laws passed based on this Act). The purpose of supplementary supervision is the protection of the financial stability of loan institutions, insurers, counter-insurance institutions and investment firms constituting part of a financial conglomerate. In the Act on Payment Services this aim is identified differently, ${ }^{19}$ because in the case of a domestic financial institution, said aim is firstly the financial security of this institution; secondly, ensuring the congruence of its activities (including the activities of its agents and entities carrying out certain operational activities based on outsourcing contracts) with the provisions of the Act on Payment Services and the relevant EC Regulation $^{20}$, and permission to carry out activities of a domestic payment institution as granted to it; thirdly, the protection of the interests of its clients. In the case of payment services bureaus, the purpose is to ensure the

\footnotetext{
17 Although the literary formulation of the provision is slightly different (art 133. 1) (narrower); as it is stressed in the doctrine, these aims should undoubtedly be interpreted more widely, Anna Dobaczewska, Nadzór bankowy, (Wydawnictwo Prawnicze Lex 1998); Jolanta Gliniecka, Jerzy Harasimowicz, Zasady polskiego prawa bankowego i dewizowego (Oficyna Wydawnicza Branta 2000) 85; Bernard Smykla, Prawo bankowe. Komentarz (CH Beck 2005) 432, Małgorzata Urban, 'Cele nadzoru bankowego w praktyce ustawodawczej' (2011) 2 Ruch Prawniczy, Ekonomiczny i Socjologiczny 173-93.

18 Act of 22 May 2003 on Supervision over Insurance and Pension Supervision and Ombudsmen of Insured Persons, Journal of Laws no 124, item 1153 as amended.

${ }^{19}$ Act of 19 August 2011 on Payment Services, Journal of Laws 2011 no 199 item 1175 as amended, hereinafter referred to as 'u.o.u.p.'

${ }^{20}$ European Parliament and Council Regulation (EC) 924/2009 of 16 September 2009 on cross-border payments in the Community and repealing Regulation (EC) 2560/2001 [2009] OJ L266/11.
} 
congruence of their actions with the provisions of the Act on Payment Services and the protection of the interests of payment services users.

In the Act on Cooperative Savings and Credit Unions, which enters into force on 27 October 2012, the purpose of supervision is different for cooperative savings and credit unions than for KSKOK. In the first case, it ensures the financial stability of cooperative savings and credit unions, the conduct of their financial activities, the safety of financial means deposited with cooperative savings and credit unions, and the congruence of the activities of cooperative credit and savings unions with the Act regulating their activities. The second aim is to ensure the financial stability of KSKOK, appropriate use of the stability fund, and the congruence of the activities of KSKOK with the provisions of the Act on Cooperative Credit and Savings Unions.

For the purpose of performing these aims, the legislator has assigned certain tasks to them which a supervisor should perform on the market as a whole $^{21}$, as well as in certain segments of the market ${ }^{22}$. The legislator has

${ }^{21}$ The tasks of the KNF in the area of financial market as a whole include:

1) supervision over the financial market, including bank supervision, pensions supervision, insurance supervision, capital market supervision, electronic money institutions supervision and supplementary supervision,

2) taking actions with the aim of securing the proper functioning of the financial market

3) taking actions with the aim of developing the financial market and its competitiveness;

4) taking actions with the aim of education and information on the functioning of the financial market;

5) participating in the preparation of drafts of legal acts on supervision over the financial market;

6) creating possibilities for amicable and conciliatory dispute resolution among the participants of the financial market; in particular, disputes arising out of contracts between entities supervised by the KNF and the recipients of the service provided by them;

7) performing other tasks as defined by legal acts.

${ }^{22}$ The tasks of the KNF in the area of the capital market include: market;

1) taking actions with the aim of securing the proper functioning of the capital

2) supervising the activities of supervised entities and the performance by these entities of their obligations related to their participation in turnover on the capital market, within limits specified by the provisions of law;

3) taking actions with the aim of education and information on the functioning of the capital market;

4) preparing drafts of legal acts related to the functioning of the capital market;

5) performing other tasks as defined by legal acts.

The authority may apply to appropriate bodies for the issuance or change of implementing provisions as set forth by legal acts.

The tasks of the KNF in the area of the insurance market and pension schemes include:

1. Based on the Act of 22 May 2003 on Insurance and Pension Supervision (art 8): 
also specified certain supplementary supervisory tasks ${ }^{23}$. In those cases where the legislator has not directly specified the tasks of the KNF, it should

1) taking actions as defined in separate provisions, with the aim of ensuring the congruence of the activities of the entities supervised with the law;

2) supervising the activities and the assets of the entities supervised;

3) performing other tasks as defined by law.

2. Based on the Act of 28 August 1997 on the Reorganisation of the Functioning of Pension Funds, consolidated text Journal of Laws 2010, no 34 item 189 as amended (art 200):

1) supervising the activities of funds;

2) analysing the shape of the pension market with respect to open pension funds, employees' pension funds and individual pension accounts in Poland, the level of security of the interests of the members of pension funds and the members of employees' pension funds, analysing threats to competition on the market of open pension funds, the development of optional and capital pension savings, maximising the level of pension savings as well as preparing proposals on changes to the law in this respect;

3) supervising the functioning of employees' pension funds;

4) improving knowledge in society on the purposes and manners of the functioning of funds, with special emphasis being placed on the rights of their members;

5 ) improving knowledge in society on the purposes and manners of functioning of employees' pension funds, with special emphasis being placed on the rights of their members;

6) co-operating with government administration, the National Bank of Poland, Social Insurance Institution, societies and entities working on behalf of funds and employees' associations, trade unions and other social organisations in respect of shaping the politics of the state to ensure the safe development of funds and employees pension funds;

7) providing the National Bank of Poland with information necessary for the performance of supervision over depository banks and banks which are shareholders of societies;

8) co-operating with foreign supervisory authorities within the performance of cross-border activities of institutions of employees' pension programs and supervision over these institutions;

9) performing other tasks as defined by law.

3. Pursuant to the Act of 22 May 2003 on Insurance Activities, consolidated text Journal of Laws 2010, no 11, item 66 as amended (art 202):

1) protecting the interests of insurers, insured persons or beneficiaries of insurance policies through preventing circumstances in which an insurer is not able to make payment as due;

2) granting licences for conducting activities of an insurer;

3 ) performing other tasks as defined by law.

23 Pursuant to the Act of 15 April 2005 on Supplementary Supervision over Loan Institutions, Insurance Institutions, Counter-insurance Institutions and Investment Firms Being a Part of a Financial Conglomerate, Journal of Laws no 83 item 719 as amended (art 54) the tasks of the KNF are:

1) gathering and making available to foreign supervision authorities information important for their performance of their statutory tasks in respect of supervision over entities working in particular sectors;

2) preparing analysis and evaluating the financial situation of a financial conglomerate;

3) evaluating the congruence of activities with the rules on capital adequacy and concentration of risks and intra-group transactions;

4) evaluating the structure, organisation and systems of internal control of a financial conglomerate; 
be assumed that, pursuant to the theory of administrative law, these tasks include the protection of values generally protected by law. Their indication in the sphere of such supervision must be made based on the general tasks of the KNF upon taking into account the norms which specify the forms of supervisory tasks and which define its competences, as well as norms of material administrative law $^{24}$. For the purpose of the performance of aims and tasks, the legislator has establishes competency norms. However, in this case it is also sometimes necessary to reconstruct some of the competencies from other norms. It should be emphasised that the Polish legislator, while replacing the supervision model in which specialised authorities exercised supervision over particular segments of financial markets and introducing in its place a model of integrated supervision, retained different types of supervisory means and a different mode of their application for each group of supervised entities, and the KNF took over the competencies of these former supervisory bodies (Banking Supervision Authority, Securities and Exchange Commission, Insurance and Pension Funds Supervision Authority $)^{25}$. This regulatory approach was also used while the group of entities supervised was expanded. This results in differentiating competencies in particular segments of the markets on the one hand, and the existence of a wide range of bases for undertaking supervisory activities sensu largo on the other. To clearly demonstrate the scope of activities of the KNF, the subject literature has established a division of competencies through grouping them in packets and attributing particular functions to them. Therefore, the three main supervisory functions usually indicated are licensing, regulatory, and oversight ${ }^{26}$, to which stricte supervisory

5) planning and coordinating ongoing supervisory tasks in co-operation with supervisory authorities as interested; acts of law.

6) performing other tasks as well as taking actions and decisions resulting out of

24 Marek Szewczyk, Nadzór $w$ materialnym prawie administracyjnym (Wydawnictwo Naukowe UAM 1995) 150 and literature as quoted therein.

${ }^{25}$ See Edyta Rutkowska, 'Problem integracji nadzoru nad rynkiem finansowym w Polsce' (2007) XVI Gdańskie Studia Prawnicze 605-19 and literature as quoted therein.

26 Dariusz Daniluk, Regulacje $i$ nadzór bankowy w Polsce (Biblioteka Menadżera i Bankowca 1996) 13; Sławomir Niemierka, 'Komisja Nadzoru Bankowego - nowy nadzorca bankowy' (1998) 9 Glosa 3ff; Włodzimierz Szpringer, Polskie regulacje bankowe. Perspektyw europejska (DIFIN 2000) 34., Edyta Rutkowska, 'Nadzór bankowy' in Eugenia Fojcik-Mastalska (ed) Prawo bankowe $w$ zarysie (Wydawnictwo Uniwersytetu Wrocławskiego 2006) 165; Bernard Smykla, 'Nadzór bankowy w ustawie o nadzorze nad rynkiem finansowym - wybrane zagadnienia' (2007) 1 Prawo Bankowe 48, Zbigniew Ofiarski, Prawo bankowe (3rd edn, Wolters Kluwer 2008) 396-401; Jacek Kołacz, Anna Stocka, Zintegrowany nadzór nad rynkiem finansowym w Polsce (PTM 2009) 80ff.

Some authors point out other functions of supervision e.g. a disciplinary function, that is, taking preventive actions, and in case of a particular threat, also proscriptive ones, with use of sanctions against a supervised entity: Dariusz Daniluk, Sławomir Niemierka, 'Nadzór bankowy w Polsce, Polski system bankowy - stan I perspektywy' (2005) 9 Bank i 
competencies (both preventive and restrictive), regulatory and organisational ones, and verification and oversight ones are attributed. However, the scope of competencies of the KNF is broader. This is because informative or mediatory competencies can also be included.

Stricte supervisory and regulatory competencies are of particular importance for further consideration. This is because in these spheres, the European legislator is introducing new mechanisms and supervisory tools whose aims are to ensure greater harmony and effectiveness of decisions taken by appropriate national supervisory authorities, which are theoretically intended to improve the stability and competitiveness of the entire European financial market.

\section{COMPETENCIES AND TASKS OF THE KNF AS A SUPERVISORY AUTHORITY OVER THE FINANCIAL MARKETS IN LIGHT OF THE REGULATION ON EUROPEAN FINANCIAL SUPERVISION}

Two pillars of the normative structure of the European supervision system have been in place since 1 January 2011: micro-prudence and macro-prudence. ${ }^{27}$ As a part of the 'macro' pillar, the European Systemic Risk Board (ESRB) was established ${ }^{28}$. Its task is to monitor and evaluate threats to financial stability within the whole EU market. The creation of the macro pillar should contribute to increased safety on the financial markets through the elimination of interrelated sector and cross-sector systemic risks $^{29}$. The main task of macro supervision is identifying threats to financial stability and deciding cases related to its supervision in a comprehensive

Kredyt 7, RW Kaszubski, Funkcjonalne źródła prawa bankowego publicznego (Wolters Kluwer 2006) 64-67, or legislative function, Rafał Blicharz, Nadzór Komisji Nadzoru Finansowego nad rynkiem kapitałowym w Polsce (Oficyna Wydawnicza Branta 2009) 57 60 and the literature as quoted therein.

${ }^{27}$ See European Parliament and Council Regulation (EU) 1092/2010 of 24 November 2010 on European Union macro-prudential oversight of the financial system and establishing a European Systemic Risk Board [2010] OJ L331/1 (ESRB Regulation); European Banking Authority Regulation; European Insurance and Occupational Pensions Authority Regulation; European Securities and Markets Authority Regulation.

For new tasks and organisation European financial supervision, see among others: Anu Arora, 'The Global Financial Crisis: A new Global Regulatory Order?' (2010) 8 JBL 2010 672; Anu Arora, 'The 2007-09 Banking Crisis and the EU`s Regulatory Response' (2010) 21 European Business Law Review 613; Elaine Fahey, 'Does the Emperor have Financial Crisis Clothes? : Reflections on the legal basis of the European Banking Authority' (2011) 74 MLR 581-95; Matthias Lehmann and Cornelia Manger-Nestler, 'Die Vorschläge zur neuen Architektur der europäischen Finanzaufsicht' (2010) 3 EuZW 88; Hannes Rehm, 'Reformen der nationalen und internationalen Finanzarchitektur' (2011) 3 Kredit und Kapital 317; Dirk Schoenmaker, 'Banking supervision and resolution: The European dimension' (2012) 6 Law and Financial Market Review 52-60.

${ }^{28}$ ESRB Regulation (n 27), art 3.

${ }^{29}$ See Commission, 'European Financial Supervision' (Communication) COM (2009) 252 final, $3 \mathrm{ff}$. 
and non-fragmentary way ${ }^{30}$. This task is to be performed through warnings against risk and recommendations issued at a Europe-wide level ${ }^{31}$. The effectiveness of the supervision under analysis depends on close cooperation among authorities within the European System of Financial Supervision (ESFS), and in particular co-operation among the authorities of the ESFS and supervisory authorities of Member States (in Poland, the $\mathrm{KNF}$ ). The basis for such co-operation in particular cases is to provide the European supervisory authorities with information about systemic risks and co-ordination of activities with international institutions: the International Monetary Fund, Financial Stability Board and appropriate authorities in other countries, in matters related to macro-prudential supervision. The European Systemic Risk Board consists of the following members: the president of the European Central Bank (ECB), who is the president of the Board; its vice-president, chosen by the members of ESRB; the presidents of the 27 central banks of the Member States; the vice president of the ECB; presidents of three European supervision authorities (ESA); a member of the European Commission; the president and two vice-presidents of the Advisory Scientific Committee and the president of the Advisory Technical Committee (the so-called General Board of the ESRB) ${ }^{32}$. Moreover, one representative of the supervisory authority of each Member State and the President of the Economic and Financial Committee take part, as observers without voting rights at the General Board of ESRB, in the meetings of the ESRB. The presence of the representative of the KNF as an observer to the ESRB is a new and a particular challenge for the KNF. Being part of the legal framework of European financial supervision, the KNF will be more effective in applying the European Union's provisions on cross-border financial services. Moreover, its coherent and comprehensive knowledge of problems facing the financial markets will provide a solid foundation for use by the KNF of supervisory instruments on a national scale. It is also worth

\footnotetext{
${ }^{30}$ Pursuant to art. 3 of the Regulation on 'macro' supervision, the ESRB is responsible for providing macro-prudential supervision over the financial system of the EU for the purpose of preventing systemic risks within the financial system or limiting these risks, to prevent periods of common financial difficulties, contribute to the smooth functioning of the internal market and ensure the permanent contribution of the financial sector to economic growth.

${ }^{31}$ Warnings can be general or specific and be directed to a particular Member State or to the whole EU, to a few Member States, to one or all European supervisory authorities or to one or more financial supervisory authorities of Member States (ESRB Regulation (n 27), art 16). Warnings and recommendations are not binding and their addressees have only the obligation to inform the ESRB about actions as taken in answer to a recommendation or on their reason for any lack of action. There is also a category of public warnings and recommendations.

${ }^{32}$ Apart from General Board of the ESRB, its organisational structure includes its Steering Committee, Secretariat, Advisory Scientific Committee, Advisory Technical Committee (ESRB Regulation (n 27), art 4).
} 
mentioning that, although supervisory authorities of Member States have been given the right to participate and speak during ESRB meetings, they are excluded from decision making. Supervisory authorities of Member States, and thereby, the KNF, can in this way obtain the information necessary for early anticipation of threats to the European and global financial markets.

As mentioned above, the second element of the new European financial supervision framework is the micro-prudential pillar. This pillar seems to be a forum for particular activity of the supervisory activities of Member States, and thereby, the KNF. Within this pillar the best and most effective mechanisms for taking decisions by supervisory authorities of Member States in relation to cross-border institutions can be insured. An important element of European supervision as introduced in this pillar is the creation of a platform for the exchange of information and experience among the supervisory authorities of Member States and the new European supervisory authorities, as well as ensuring the uniform interpretation of legal provisions together with gathering micro-prudential information. The European supervision network as implemented in the micro pillar consists of European supervisory authorities over three segments of the EU's financial markets: banking (EBA - the European Banking Authority ${ }^{33}$ ), insurance (EIOPA - the European Insurance and Occupational Pensions Authority $^{34}$ ) and capital (ESMA - the European Securities and Markets Authority ${ }^{35}$ ), the Joint Committee of European Supervisory Authorities, and the relevant authorities and/or supervisory authorities of the Member States. It is worth mentioning that each ESA consists of a Council of Supervisory Authorities (which consists of the presidents of the European supervisory authorities and presidents of the appropriate supervisory authorities of the Member States, thereby also KNF, one representative of the EC, one representative of the ECB, one representative of the ESRB and one representative from each remaining $\mathrm{ESA}^{36}$ ); and in addition, the Management Board, the Chairmen, Executive Director and Board of Appeal, pursuant to art. 6 of the Regulation on ESA. Based on art. 45 of the Regulation on ESA, the Management Board of each of the European Supervisory Authorities is composed of the Chairmen and six other members of the Board of Supervisors chosen from and by the members with voting rights of the Supervisors Board.

Financial supervisory authorities of Member States take part in the work of the ESFS. While analysing the solutions comprising the micro pillar, it is important to notice that ongoing supervision is performed at the Member State level, as it has been to date. The supervisory authorities of Member States still exercise individual supervision over particular entities -

\footnotetext{
${ }^{33}$ European Banking Authority Regulation.

${ }^{34}$ See European Insurance and Occupational Pensions Authority Regulation.

${ }^{35}$ See European Securities and Markets Authority Regulation.

${ }^{36}$ European Insurance and Occupational Pensions Authority Regulation, art 40; European Securities and Markets Authority Regulation, art 40; European Banking Authority Regulation, art 40.
} 
participants in the financial market - as well as consolidated supervision. Some innovative solutions include, firstly, that particular tasks are centralised on a Europe-wide level; secondly, harmonisation of the provisions and consistent supervisory practices (a creation of a uniform set of EU provisions for all financial institutions on the markets) ${ }^{37}$ are promoted; thirdly, they are implemented pursuant to the principles of partnership, aid and flexibility ${ }^{38}$. It is a particularly important solution that European supervisory authorities will provide interpretation recommendations to which the financial authorities of Member States will have to adhere to while taking decisions, in particular those related to licences for financial institutions. A ground-breaking solution from the European legislator is providing European supervisory authorities with competencies for licensing certain entities with a pan-European range of activities (e.g. rating agencies), and in extraordinary circumstances the ESA will also be able to take a decision directed at a financial institution when a supervisory authority of a Member State does not adhere to a decision of the Commission, or when a supervisory authority of a Member State faced with a cross-border crisis situation will not be able to react promptly ${ }^{39}$.

It should be emphasised that the efficiency of the new supervision regime in the EU depends on the one hand on the co-operation between the 'macro' and 'micro' pillars of supervision and between European financial authorities and the financial authorities of Member States on the other. This means that the scope of the KNF's activities should be adjusted to the new legislative situation. Based on the above analysis, it may be stated that the new areas, tasks, duties and competencies of the KNF following the entry into force of the ESFS include: firstly, ensuring adherence to the uniform set of provisions of the EU on the activities of financial institutions on a

\footnotetext{
${ }^{37}$ It is worth emphasising that the European legislator envisaged that ensuring a coherent application of EU provisions is one of the most important tasks of the ESFS. That is why in the case of discrepancies in the opinions of financial authorities of Member States, the European supervisory authorities should simplify communication and lead to a settlement between the supervisory authorities of said Member States. One of the important elements of the supervisory system is a mechanism for actions in case of a material breach of EU law.

${ }^{38}$ Communication (n 29) $5 \mathrm{ff}$.

39 See European Banking Authority Regulation art 17, 18, 19; European Insurance and Occupational Pensions Authority Regulation, art 17, 18, 19; European Securities and Markets Authority Regulation art 17, 18, 19.

The subject of decisions of the ESA and on the issue of the need for amendments to the Administrative Procedure Code and/or the act on the Supervision over the financial market have been also widely commented on by Magdalena Fedorowicz, Andrzej Michór, 'O charakterze prawnym decyzji nowych europejskich organów nadzoru nad rynkiem finansowym UE’ (2011) 11 Europejski Przegląd Sądowy 24-35.
} 
uniform market, contained in Binding Technical Standards ${ }^{40}$; secondly, creating in the national law an appropriate mechanism to co-ordinate the cooperation between the KNF and European financial supervision authorities in respect of 'micro supervision' and representation, tasks, and duties of the KNF's representatives in respect of macro supervision; thirdly, developing internal regulations for matters related to deciding disputes between national supervisory authorities ${ }^{41}$.

New regulations at the EU level have to be reflected in the law of its Member States. It is natural that, although the KNF is obliged to obey the provisions of EU law, one cannot exclude a situation in which there will be a need to introduce into the Polish legal system legal solutions allowing for more effective achievement of aims of European regulations.

Based on the changes made in European law, it can be said that harmonisation on the Member State level should be established both in the form of acts of Parliament and norms at lower ranks. It seems justified to add new tasks to the current one of the KNF due to the fact that the present catalogue of these tasks (among others, actions taken by the KNF aimed at the proper functioning of the financial markets) could encompass to a greater extent the performance of tasks within the ESFS. Upon the entry into force of ESFS regulation, the KNF's tasks consist in taking actions for the purpose of ensuring the stability of the domestic financial system through co-operation with the ESA and co-ordination of activities within the ESFS, as a result of which a domestic supervisor ensures the proper functioning of its domestic market and, through co-operation with ESFS, the uniform financial market of the EU.

This should be accomplished not only through assigning new competencies (e.g. for the KNF, filing applications with the ESA in the case of supervisory authorities of a Member State not adhering to EU law, or for the chairmen of the KNF and the representatives of the KNF in the management of the European supervisory authorities to provide information (including confidential information within the scope necessary for performing tasks resulting from participation in $\mathrm{ESFS}^{42}$ ), but also through working out appropriate procedures for co-operation, co-ordination and exchange of information or procedures to be used in the case of refusal to

\footnotetext{
${ }^{40}$ On the subject of the BTS and other instruments of the ESFS impact on the financial markets see Magdalena Fedorowicz, 'Regulacja nadzoru nad rynkiem finansowym w UE integracja czy dezintegracja prawnych instrumentów antykryzysowych' (2011) 7 Ekonomia i Prawo 287-303.

${ }^{41}$ It is worth emphasising, however, that the issues mentioned are regulated at the European level. Irrespective of the aforementioned, it seems that the domestic legislator must also set forth in the provisions of law new tasks, aims and duties for the KNF, with emphasis being placed in particular on creating a mechanism for the exchange of information and coordination. On the issue of the relationship between the ESA and the KNF see Magdalena Fedorowicz, 'Współpraca między Europejskimi Urzędami Nadzoru Finansowego a Komisją Nadzoru Finansowego w zakresie nadzoru nad rynkiem finansowym w UE' in Nadzór nad rynkiem finansowym Eugenia Fojcik-Mastalska and Edyta Rutkowska-Tomaszewska (eds) Aktualne tendencje i problemy dyskusyjne, [2011] 1 Seria Studia Finansowoprawne 31-44.

${ }^{42}$ An equivalent of existing art 17 paras 1 and 3 u.n.n.r.f.
} 
adhere to the ESA's recommendations. This could be accomplished by developing internally-binding legal norms.

It should also be said that, while making appropriate changes in legislation, the legislator should also ensure that the contents of EU regulations are not repeated in an act of parliament as the legislator could face a charge of breaching the EU law ${ }^{43}$.

\section{THE IMPORTANCE OF THE KNF AS AN ELEMENT OF A SAFETY NET}

As a result of the changes introduced at the European level, the KNF may be said to have a dual role. On the one hand, it guarantees financial stability and transparency on the domestic market, and on the other hand, within the framework of the European Financial Supervision System, it creates together with other national supervision authorities a complete system of safety for the European Union market.

The introduction of the European financial supervision system undoubtedly reinforces financial supervision in Europe. One can assume that this reinforcement will also result in an increase in the role and importance of domestic supervisory authorities over the financial markets, being an important part of the financial markets' safety net. On the other hand, the strengthening of European supervision may also mean that there will be additional tasks assigned to supervisors of the Member States. One may theorise that the efficiency of European financial supervision will depend on the activity of domestic financial supervision authorities. The fact of limiting certain competencies of the KNF related to decision-taking as a result of moving this process to the European level should be explained by improved effectiveness at this particular level.

The implementation of the new European supervisory framework also means that the standards of supervision for domestic supervision authorities will be improved, as will the uniformity and coherence of the use of supervisory standards.

\section{CONCLUDING REMARKS}

In conclusion, it must be said that the implementation of a new supervisory structure in the EU has brought about changes to the functioning of the KNF. These changes are particularly visible in the

\footnotetext{
${ }^{43}$ See Jan Barcz, Zapewnienie skuteczności prawu UE w prawie polskim. Wytyczne polityki legislacyjnej i techniki prawodawczej (UKIE Biblioteka Europejska 2003) 12.
} 
regulatory functions, as domestic supervisory authorities are obliged to introduce uniform supervisory standards defined at the European level. Moreover, the stricte supervisory function of $\mathrm{KNF}$ is also altered, in particular through limitation of the performance of supervisory competencies towards financial institutions in the circumstances defined by EU law. Undoubtedly, the regulation of financial structures in the EU as implemented poses certain challenges to the Polish Financial Supervision Authority and is the source of a lively debate over the new approach to functions and competencies, tasks, and purposes of this body supervising the financial market. This paper is a contribution to the discussion on the course of the development of Polish and EU financial markets supervision.

The current role of the FSA in the new European financial supervisory structure will probably be the subject of wider debate because the solutions discussed in the paper are part of the evolution of the supervisory structure, whose next step on the road to further integration is taking place now. These considerations are of a pioneering nature to some extent, therefore searching for an answer to the research problem as posed at the beginning first required an analysis of the law in force to be conducted, as it would be difficult to find answers to questions currently arising by making greater reference to the views of doctrine and jurisprudence. This is due to the fact that the present discourse on the role of national supervisors has just started. As a result, there is a limited number of scientific publications in this field and no relevant judicial decisions have been handed down yet.

Undoubtedly, however, it could already be said that the current reform of the European financial markets has shown that the role of national supervisors in the financial safety net requires a new approach. It is obvious that in these times of financial crisis, national supervisors have to incur significant costs, namely the functional reduction of regulatory independence in some matters. 